\title{
市县“双评价”中优势农业空间划定研究： 理论、方法和案例
}

\author{
苏鹤放 ${ }^{1}$, 曹根榕 ${ }^{1}$, 顾朝林 ${ }^{1}$, 金家梁 $^{2}$, \\ 张晓明 ${ }^{3}$, 易好否 ${ }^{1}$, 郑 毅 $^{1}$, 傅 强 $^{4}$
}

(1. 清华大学建筑学院, 北京 $100084 ; 2$. 中国城市科学规划设计研究院, 北京 $100835 ; 3$. 国家发展和改革委 员会城市和小城镇改革发展中心, 北京 100824;4. 山东科技大学土木工程与建筑学院,青岛 266590）

\begin{abstract}
摘要: 我国城镇化迅速龺食宝贵的耕地资源和乡村聚落,保护基本农田、保护乡村、保护农业 空间的需求迫在眉睫。新一轮市县国土空间规划“双评价”中, 针对“农业空间”只重视基本农 田和粮食生产的不足, 旨在构建“优势农业空间”划定的理论框架和技术方法, 为保护农林牧副 渔大农业空间、全农业领域生产者和特色、重点农村地区奠定基础。(1)在生态保护极重要区以 外, 开展全域、全要素的种植业、畜牧业、渔业生产适宜性评价, 识别农业生产适宜区和不适宜 区; (2) 基于高产稳产、规模经营和集中连片三原则, 进一步细化评价重要经济作物适宜区、地 域特色农产品适宜区等; (3) 在此基础上, 结合特色村落、重大农业基础设施要素识别优势农业 空间。该技术框架在沈阳和温州市县 “双评价” 中取得了科学实用的评价成果, 为我国正在展 开的国土空间规划提供了科学支撑。
\end{abstract}

关键词：优势农业空间;国土空间规划;城镇化;农业空间保护;多要素综合评价

改革开放以来，在快速城镇化的驱动下，中国农村剩余劳动力外流，耕地保护压力 加大, 乡村衰退日趋严重。保护耕地、保护农村、保护农业的需求十分紧迫 ${ }^{[1]}$ 。我国快速 城镇化正在虫食优势农业空间，保护基本农田、保护乡村、保护农业空间刻不容缓。新 一轮市县国土空间规划中的资源环境承载能力和国土空间开发适宜性评价（简称 “双评 价”)，无疑可以为遏制这样的牺牲农业空间的城镇化趋势提供科学的决策支撑。面向国 土空间规划编制的新形势与新要求，各地相继组织开展了 “双评价” 工作 ${ }^{[2,3]}$ 。当前 “双 评价” 实践中的评价路线已能够有效分析国土空间本底条件，为优化国土空间开发保护 格局和编制国土空间规划提供依据。然而，从已有实践中农业功能指向的 “双评价” 来 看，仍然存在以下不足：（1）在评价方法方面，农业生产适宜性评价采用的是多指标综 合叠置分析方法, 方法虽简单易操作, 但也造成集成评价结果中部分单要素评价信息的 缺失;（2）在评价内容方面，缺少对特色重点村落、重大农业基础设施和地域特色优势 农产品的考虑，造成现阶段市县评价成果在国土空间规划体系的乡村地区规划编制中应 用不足；（3）在评价指标方面，更关注与农业生产相关的水资源和土地资源等指标，对 粮食和重要农产品、地域特色优势农产品的产量以及农业生产经营规模等指标欠缺考

收稿日期：2020-03-06; 修订日期：2020-06-29

基金项目：国家重点研发计划（2018YFD1100105); 国家自然科学基金重大项目（41590844）

作者简介: 苏鹤放 (1997-), 女, 安徽芜湖人, 博士研究生, 研究方向为城市地理和城市规划。 E-mail: 502307071@qq.com

通讯作者: 顾朝林 (1958- ), 男, 江苏靖江人, 博士, 教授, 博士生导师, 研究方向为城市地理学、城市与区域规 划。E-mail: gucl@tsinghua.edu.cn 
虑。本文基于 “永久基本农田保护红线” 提出 “优势农业空间” 概念, 强调对粮食生产 保护区和特色农副产品保护区（简称 “两区”）的划定，提出在综合考虑农业生产适宜 性、农业生产保护区、村落保护区和重大农业基础设施保护区等要素基础上，运用TOPSIS 模型和判别矩阵法, 识别划定农业重点保护和发展区域, 并以沈阳和温州为例, 进行 市县层面 “双评价” 中 “优势农业空间” 的评价和划定，以期为我国正在展开的国土空 间规划提供更加科学的支撑。

\section{1 研究方法与数据来源}

\section{1 文献回顾}

在国家主体功能区规划和多部委 “多规合一” 空间规划体系改革试点背景下，由于 耕地和建设用地的管理部门事权分散，“农业空间” 只关注 “粮食安全” 的国家基本农田 保护区，对农林牧副渔大农业空间、全农业领域生产者和特色、重点农村地区的保护关 注不够 ${ }^{[1]}$ 。鉴于此，顾朝林等最早提出划定 “永久农村地区”，保护优势农业空间的想 法，并明确提出了 “永久农村地区” 是指以乡或村为基本地域单元，依托国家永久基本 农田保护区，未来永久保留农村地域景观风貌、永久从事农业生产并以农业和农村现代 化建设为主要内容的地区 ${ }^{[4,5]}$ 。划定的 “永久农村地区” 主要包括：（1）具有区域发展优 势的农林牧副渔生产区;（2）以村庄为单元具有地域特色的传统乡村文化保留区，以及 以农业观光、旅游等为主要产业的农村传统风貌保留较完好的村落;（3）景观特色的农 业生态用地和农业大地景观地区 ${ }^{[4,5]}$ 。“永久农村地区”的划定，旨在维护基本粮食生产安 全和稳定农业发展; 同时与城镇开发边界和生态保护红线相衔接，控制城镇建设规模和 范围；保护农村生态环境，传承乡村地域特色。

当前, 我国正全面开展新一轮国土空间规划编制工作 ${ }^{[6]}$, 其中一项重要任务就是切实 保障国家粮食安全 ${ }^{[7]}$ ，建设绿色安全的农产品供给空间 ${ }^{[8]}$ ，摸清并确保粮食生产安全的 “底线” ${ }^{[9]}$ 。同时，在国家实施乡村振兴战略背景下，市县层面国土空间规划还应统筹谋 划乡村振兴格局、制定乡村空间治理策略，通过空间资源要素配置与用途管制来推进乡 村地域的空间重构，发挥对乡村振兴战略的重要支撑作用 ${ }^{[10,11]}$ 。然而，基于传统的 “双评 价” 划定的农业空间仅注重对 “粮食生产” 的基本农田保护和利用 ${ }^{[12]}$ ，无法充分发挥服 务于市县级国土空间规划中对农林牧副渔及特色农业空间的保护和格局优化的作用。因 此，本文提出优势农业空间的划定，即以国家基本农田保护区为依托，特别强调粮食生 产安全和特色农副产品生产效益, 并引入农业生产三要素评价, 作为划分优势农业空间 的依据一一高产稳产评价服务于保障粮食生产安全的目的; 规模经营评价服务于优化农 业发展效益的目的; 集中连片评价服务于提高农业生产质量的目的。

农业高产稳产评价是确立农业生产保障粮食安全和主要农产品供给能力的基础。高 产稳产是判断农作物品种特性和优劣的重要标准 ${ }^{[13]}$ 。在早期研究中, 高产和稳产评价指 标相互独立 ${ }^{[14]}$, 通过农作物单位面积产量数据及其标准差、变异系数、回归系数进行测 度, 将产量水平和稳定性区别评价的方法适用于评价对象的简单分类，对农业生产的指 导意义较弱; 随着研究深人, 基于对高产性和稳产性相互协同的认知, 部分学者提出高 稳系数法、坐标图象限法以综合评价农作物高产稳产水平。其中, 高稳系数法 ${ }^{[15,16]}$ 通过高 稳系数对评价对象的高产稳产性进行综合量化与排序, 计算过程简便、评价效果科学, 
对分析农业生产能力、划定优势农业空间具有良好的参考价值。

农业规模经营评价是面向我国小农经济模式现代化改造的必然趋势，是稳固粮食生 产、促进农业增效和农民增收的又一有力保障。农业规模经营理论源于经济学的规模报 酬变化原理，指在一定的生产力水平和经营环境条件下，通过优化配置劳动力、资本、 技术等多种生产要素, 实现平均生产成本的降低和土地生产效率的提高, 从而达到经济 效益最大化的目标 ${ }^{[17]}$ 。实证研究表明，农业规模经营水平受制度环境、区域环境、市场 环境、生产者特征等宏观、微观多层次因素影响 ${ }^{[18]}$ 。农产品规模经营评价涉及不同区 域、品种的差异性和复杂性问题。纵览我国农业政策，促进农村土地有序流转、培育新 型农业经营主体和健全农业社会化服务体系是深化农业改革和推进农业适度规模经营的 三大基本途径。其中，新型农业经营主体包括专业大户、家庭农场、农民合作社等 ${ }^{[19]}$ ，在

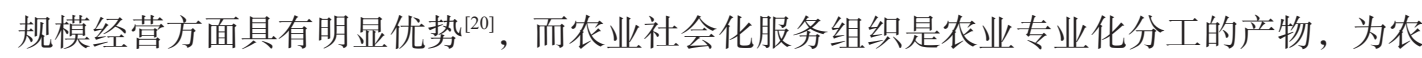
户提供产前、产中、产后等多层次农业生产性服务 ${ }^{[21,22]}$ 。此外，基于不同利益相关者的目 标, 农业规模经营标准的测度有不同方法 ${ }^{[23,24]}$ 。经济学家基于农业生产参数多元函数模型 估测农户利润最大化时的经营规模，称为效益尺度法 ${ }^{[25-28]}$ 。相比之下，从农户视角出发的 收人尺度法 ${ }^{[29-31]}$ 基于务农利润和农民收人目标定量估算不同农业生产者的适度规模经营标 准，在我国农业规模经营受土地资源稀缺制约的基本国情下应用更广。农业规模经营评 价受上述多样化影响因子和评价视角作用, 需要综合考虑粮食生产、农民收人、农业劳 动力转移等战略因素和现实条件 ${ }^{[2]}$ 。在我国人地比例偏高的自然禀赋约束下, 农业规模 经营评价宜围绕农民主体的收人视角, 兼顾粮食安全和主要农产品供给的战略需求。

农田集中连片评价在高产稳产和规模经营评价基础上，进一步推动农业生产经营土 地条件的改善。连片性（Connectivity）也称连通性，原指景观连通性（Landscape Connectivity), 是景观生态学领域描述景观中廊道或基质在空间上如何连接和延续的一项指 标 ${ }^{[33-35]}$ 。“连片性” 概念最早被周尚意等 ${ }^{[36}$ 引人基本农田保护规划，指同一质量范围（同 一利用类型或同一质量水平，或某一质量水平以上，或某质量水平区间内）农田地块的 相连程度。农田连片性评价方法概括为: 第一，基于某种空间分析和计算方法对农田地 块进行连接，如空间相连性分析、缓冲区分析和二值形态闭运算法 ${ }^{[36-38}$; 第二，通过景观 格局指数反映研究区域整体连片性, 如斑块平均面积、斑块边界密度和最大斑块指数 ${ }^{[39]}$; 第三, 计算单个农田斑块或小邻域单元的局部连片性, 指标包括平均欧式邻近距离、模 糊纹理指数、基本农田保护指数和基于连片网络的局部连片度指数 ${ }^{[3-42]}$ 。比较而言, 空间 分析法和景观格局指数法以农田整体连片性为运算对象, 评价精度和效用较低, 而局部 连片性法通过划分地块连片性等级精准识别集中连片和破碎耕地，可支撑市县级基本农 田优化调整和优势农业空间划定。

综上所述，划定优势农业空间需要在传统 “双评价” 的资源环境要素基础上综合考 虑高产稳产、规模经营和集中连片要素，重点巩固粮食生产和保护农业资源; 同时将农 业农村现代化和传统乡村地域文化保护纳人考虑，从而为乡村振兴战略下乡村规划编制 和实施提供依据。不难发现, 真正的优势农业空间, 包含以下三类要素：（1）具备高产 稳产、规模经营、集中连片特征的农业生产保护区;（2）现代化农村和传统特色乡村聚 落组成的村落保护区;（3）维护区域农业生产服务功能的重大农业基础设施保护区。系 统地收集数据, 科学地评价相关要素, 可以找出一个地区的 “优势农业空间”。然而, 如 何进行市县国土空间规划 “双评价” 中 “优势农业空间” 的科学评价, 相关研究主要从 
概念与内涵人手奠定了基础评价框架，涉及评价方法、成果应用的系统化分析和实证研 究十分稀缺。本文由此完善与细化优势农业空间评价体系，尝试构建科学、系统、简 洁、便于使用的划定方法，并以沈阳和温州为例进一步开展评价成果与效用的实证探索。

\section{2 评价体系构建}

优势农业空间评价和划定体系包含农业生产功能指向的生产适宜性评价、农业生产 区、村落保护区、重大农业基础设施保护区评价四个方面（图 1)，在地方农业生产自然 资源、自然环境和自然灾害等本底条件评价的基础上，以满足市县级 “双评价” 层面深 度评价需求为宗旨，保障粮食生产安全和永久基本农田稳固，进一步深化和优化 “农业 空间” 评价以及对于特色农林牧副渔产品生产区、全农业领域生产者、特色重点农村地 区和重大农业基础设施的保护。

\begin{tabular}{|c|c|c|c|}
\hline 坡度 & 农业功能指向的 \\
土地资源评价
\end{tabular}

图 1 优势农业空间评价体系

Fig. 1 Evaluation schemes of superior agricultural space

遵照 “系统采集数据” “简化评价过程” “成果科学实用” 的要求，在统一数据平台 的基础上，通过市县国土空间规划层面农业生产功能指向的适宜性评价、农业生产保护 区、村落保护区和重大农业基础设施保护区评价，以及多要素综合评价方法，划定优势 农业空间。技术路线如图 2 所示。

\section{3 数据采集与处理}

数据来源主要为沈阳市和温州市相关政府单位提供的官方数据（表 1), 具体分为: （1）农业生产本底条件类数据：涉及土地资源类、水资源类、气象气候类和灾害类等农 业生产适宜性评价数据;（2）社会经济类数据：乡镇人口普查数据和各类统计年鉴数 据;（3）村落保护类数据：官方评定的乡村振兴示范村、国家级省级传统村落和历史文 化名村、少数民族特色村寨;（4）农业基础设施类数据：区域重大农业基础设施数量、 等级和分布；（5）生态协调类数据：生态保护红线和重要生态保护区;（6）基础底图类 数据;（7）相关规划类数据。基于优势农业空间划定技术路线，对原始数据重组为农业 生产数据库、村落保护数据库和重大农业基础设施数据库。针对评价中间过程和最终环 


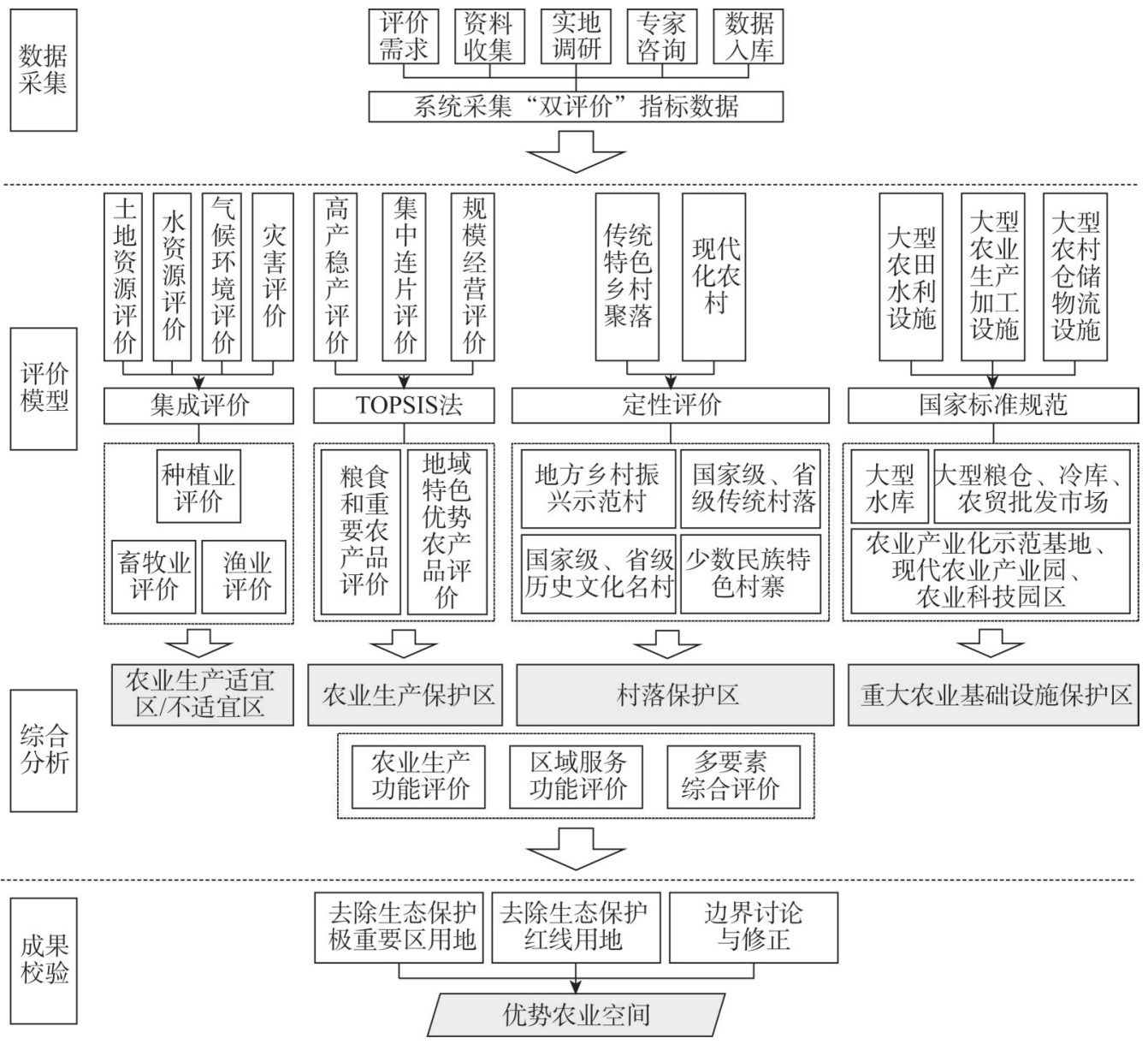

图2 优势农业空间划定技术路线

Fig. 2 Technical route of superior agricultural space demarcation

表 1 “双评价” 优势农业空间划定数据需求表

Table 1 Data requirement list of superior agricultural space demarcation

\begin{tabular}{|c|c|}
\hline 数据类别 & 数据内容 \\
\hline 农业生 土地资源类 & 第三次全国国土调查数据, DEM数据, 土壤质地分类数据, 土壤调查监测数据 \\
\hline $\begin{array}{l}\text { 产本底 水资源类 } \\
\text { 条件类 }\end{array}$ & 水资源调查数据, 水资源公报, 水资源流域分区, 水质监测数据及相关图件 \\
\hline 气象气候类 & 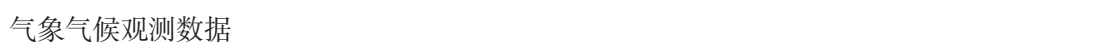 \\
\hline 灾害类 & 地震灾害活动断层分布图, 地质灾害易发区数据, 气象灾害数据, 水文灾害数据等 \\
\hline 社会经济类 & 乡镇人口普查数据, 市统计年鉴、农业统计年鉴数据 \\
\hline 村落保护类 & 乡村振兴示范村, 国家级、省级传统村落和历史文化名村, 少数民族特色村寨 \\
\hline 农业基础设施类 & $\begin{array}{l}\text { 大型农田水利设施, 大型农业生产加工设施, 大型农村仓储物流设施, 大型海洋水产增 } \\
\text { 养殖区等 }\end{array}$ \\
\hline 生态协调类 & $\begin{array}{l}\text { 生态红线数据, 水源涵养区、自然保护区、森林公园、海洋保护区、水产种质资源保护 } \\
\text { 区等 }\end{array}$ \\
\hline 基础底图类 & 永久基本农田, 基础性地理国情监测数据, 建成区和中心城区范围, 行政区划 \\
\hline 相关规划类 & $\begin{array}{l}\text { 多规合一规划、总体规划、环保规划、国土规划、发改规划、林业规划、海洋规划、住 } \\
\text { 建规划等 }\end{array}$ \\
\hline
\end{tabular}


节涉及的多指标信息综合分析、整体研判和横向比较问题，对采集到的原始指标进行极 差标准化处理，以消除多个指标单位和量纲不同造成的误差，确保结果的可靠性。

\section{4 评价方法}

\section{4 .1 单要素评价}

在农业生产适宜性评价、农业生产保护区、村落保护区、重大农业基础设施保护区 划分的基础上, 开展农业生产功能和区域服务功能单要素评价, 作为进一步划定优势农 业空间的评价依据。

\section{（1）农业生产功能评价}

农业生产功能评价以农业生产三要素（高产稳产、规模经营和集中连片）综合评价 结果为指标, 由粮食作物、重要农产品和特色农副产品的生产能力共同决定。 $T_{i j}$ 代表乡 镇 $j$ 对农产品 $i$ 的综合生产能力, 对 $q$ 个 $T_{i j}$ 评价结果进行求和, 得到农业生产功能总体评 价结果。计算公式为:

$$
T_{j}=\sqrt{\sum_{i=1}^{q} T_{i j}^{2}}
$$

式中： $T_{j}$ 代表乡镇 $j$ 农业生产功能水平； $q$ 代表乡镇 $j$ 农业生产保护区评价中农产品种类 数量（种)。根据划定单元将 $T_{j}$ 赋值给乡镇 $j$ 内行政村单元。

(2) 区域服务功能评价

基于重大农业基础设施识别，对村庄 $j$ 构建区域服务功能评价指标阵列 $\left(X_{j}, Y_{j}, Z_{j}\right)$, 其中, $X_{j}$ 为村庄大型水库及其缓冲区面积占村域面积比例 $(\%), Y_{j}$ 和 $Z_{j}$ 分别为村庄大 型农业生产加工设施和大型仓储物流设施数量 (个)。计算公式为:

$$
L N_{j}=\sqrt{\left(X_{j}^{\prime}\right)^{2}+\left(Y_{j}^{\prime}\right)^{2}+\left(Z_{j}^{\prime}\right)^{2}}
$$

式中: $L N_{j}$ 代表村庄 $j$ 区域服务功能水平 ; $X_{j}^{\prime} 、 Y_{j}^{\prime}$ 和 $Z_{j}^{\prime}$ 分别为村庄 $j$ 的区域服务功能评 价指标标准值。

\subsection{2 多要素综合评价}

多要素（或多指标）综合评价方法是多目标或多属性评估中，对评价对象进行全面 整体研判的重要手段, 也是进行横向比较和优选排序的决策基础。TOPSIS 法是一种应用 广泛的多要素综合评价定量模型, 它以标准化矩阵中评价对象与理想解的相对接近度作 为综合评价的依据，具有计算简便、适用性广、对原始数据利用充分的优点，广泛应用

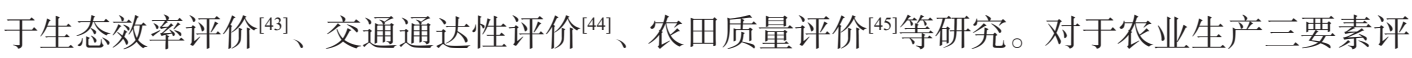
价, 利用TOPSIS 法对高产稳产、规模经营和集中连片三个评价维度进行综合分析, 划定 粮食、重要农产品和特色农林牧副渔产品的生产区。基本模型 ${ }^{[46]}$ 为:

$$
T_{i}=\frac{D_{i}^{-}}{D_{i}^{-}+D_{i}^{+}}(i=1,2, \cdots, n)
$$

式中： $T_{i}$ 代表评价对象 $i$ 和理想解之间的相对接近度； $D_{i}^{-}$代表评价对象 $i$ 和最劣解之间 的距离; $D_{i}^{+}$代表评价对象 $i$ 和最优解之间的距离; $n$ 代表评价对象数量 (个)。

基于对农业生产功能、区域服务功能和村落保护区三个要素组合的观察与分析，利 用多要素综合评价矩阵作出划定优势农业空间范围的定性决策。采用Natural Breaks 法将 单要素评价的农业生产功能水平 $\left(T_{j}\right)$ 和区域服务功能水平 $\left(L N_{j}\right)$ 分为强、中、弱三 
等, 结合村落保护区划定结果, 构成 “ $3 \times 3 \times 2$ ” 的三维矩阵 (图 3), 理 论上具有 18 种要素组合方式。优势 农业空间包括:（1）农业生产功能较 强的单元;（2）农业生产功能中等, 具有较强的区域服务功能或属于村 落保护区的单元;（3）农业生产功 能弱, 具有较强的区域服务功能, 且属于村落保护区的单元。

\section{2 结果分析}

基于上述理论与方法，本文对沈

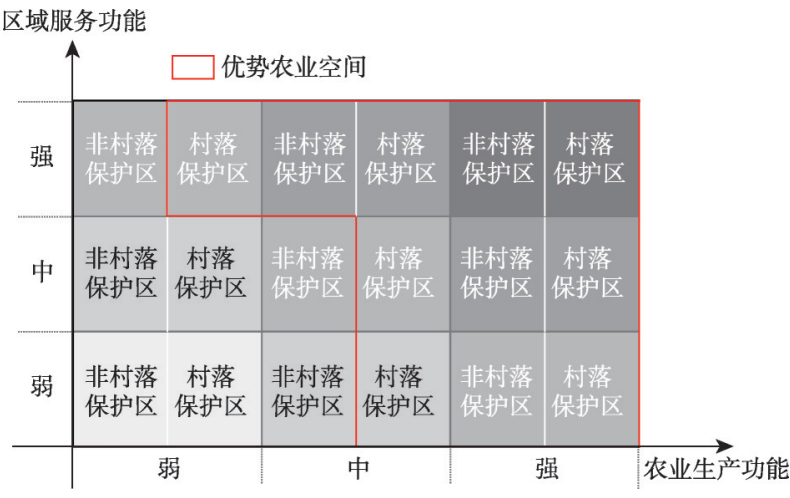

图3 优势农业空间划定的多要素综合评价矩阵

Fig. 3 Multi-factor comprehensive evaluation matrix of superior agricultural space demarcation

阳、温州市县国土空间规划 “双评价” 中的 “农业空间” 进行评价，划定了 “优势农业 空间”。温州市和沈阳市在资源环境禀赋方面具有典型的不同特征：温州市地形复杂，土 地资源是农业生产最主要的约束条件, 此外，丰富的海洋资源使得海洋渔业生产保护区 成为重要评价内容之一; 沈阳市地势平坦, 水资源是农业生产最主要的约束条件, 由于 城镇建成区周边土壤污染，环境要素成为重要考虑因素之一。由于两个案例地区位和自 身禀赋的差异，评价过程中遴选了差异化评价指标，尤其注重对影响两个地区国土空间 开发限制性 “短板要素” 的指标选取 ${ }^{[47]}$, 同时设置差异化评价参数以及分级國值，例如 温州特色农业茶园地区的坡度分级國值与沈阳以粮食作物为主的耕地坡度分级國值的差 异化设置。两个典型案例分别代表了沿海地区和内陆地区、南方和北方、土地资源约束 和水资源约束的评价，以期为全国不同地区开展的 “双评价” 和国土空间规划提供借鉴。

\section{1 农业生产适宜性评价}

沈阳市农业生产适宜性评价表明现状农田 $86 \%$ 属于农业生产适宜区与较适宜区，农 业生产不适宜区仅占 2.4\%（图 4)，康平县、法库县等面临严峻水资源短缺形势和保护压 力的地区的农业生产适宜性显著不利。此外，土壤环境质量评价识别沈阳市永久基本农 田中存在严重污染（有毒）面积为 $6.74 \mathrm{~km}^{2}$, 对于受城镇污染、不宜继续发展农业生产 功能的基本农田，考虑从农用地安全利用的角度逐步退出农业空间，积极推进农田生态 修复和退耕还林、还草、还湖、还湿的生态工程（图 5)。

\section{2 农业生产保护区划分}

根据高产稳产、规模经营和集中连片的农业生产保护区评价，沈阳市粮食和重要农 产品集中生产区总面积 $4981.13 \mathrm{~km}^{2}$ ，占现状永久基本农田面积的 78.5\%（图 6); 沈阳市 地域特色优势农产品集中生产区共计 491 个行政村（图 7)。由于温州市具有海域面积广 阔、海洋资源丰富的地理区位和自然禀赋优势，在陆域农业生产保护区评价以外尤其注 重可利用海域的评价。根据海洋养殖和海水捕捞的生产方式特征和利用资源现状，划定 海洋渔业生产保护区总面积 $587.91 \mathrm{~km}^{2}$, 包含约 $172 \mathrm{~km}^{2}$ 大型海域水产养殖区, 7 处水产 种质资源保护区和 2 处增殖区，以及 11 处渔港（图 8)。

\section{3 优势农业空间划定}

基于本文构建的市县 “双评价” 中优势农业空间划定方法，划定沈阳市优势农业空 间总面积 $2409.83 \mathrm{~km}^{2}$, 占沈阳市国土面积的 $19 \%$, 包含 276 个村庄单元（图 9); 划定温 


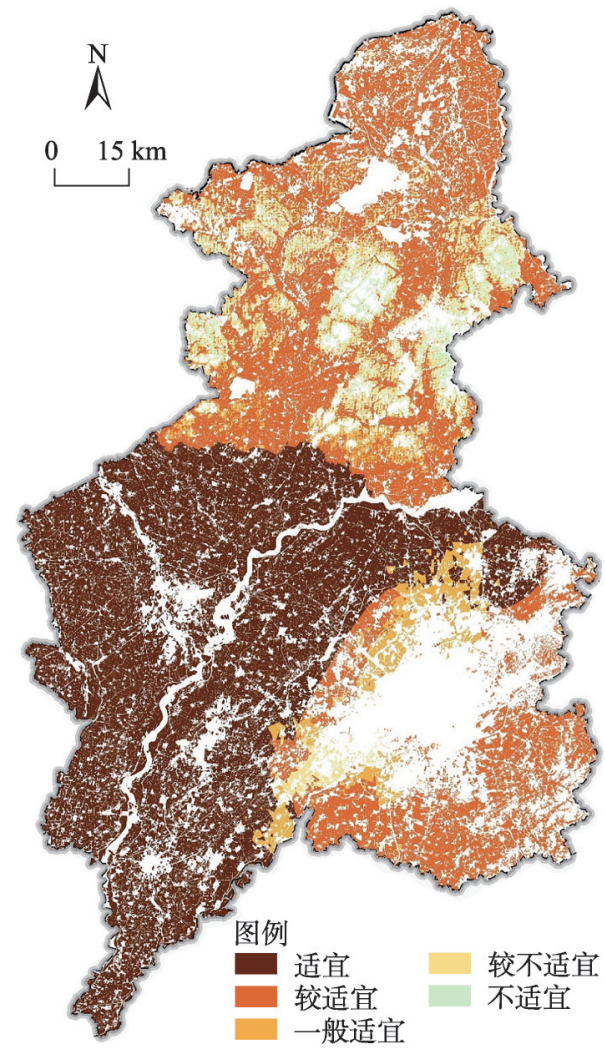

图 4 沈阳耕地适宜性评价

Fig. 4 Assessment of arable land suitability

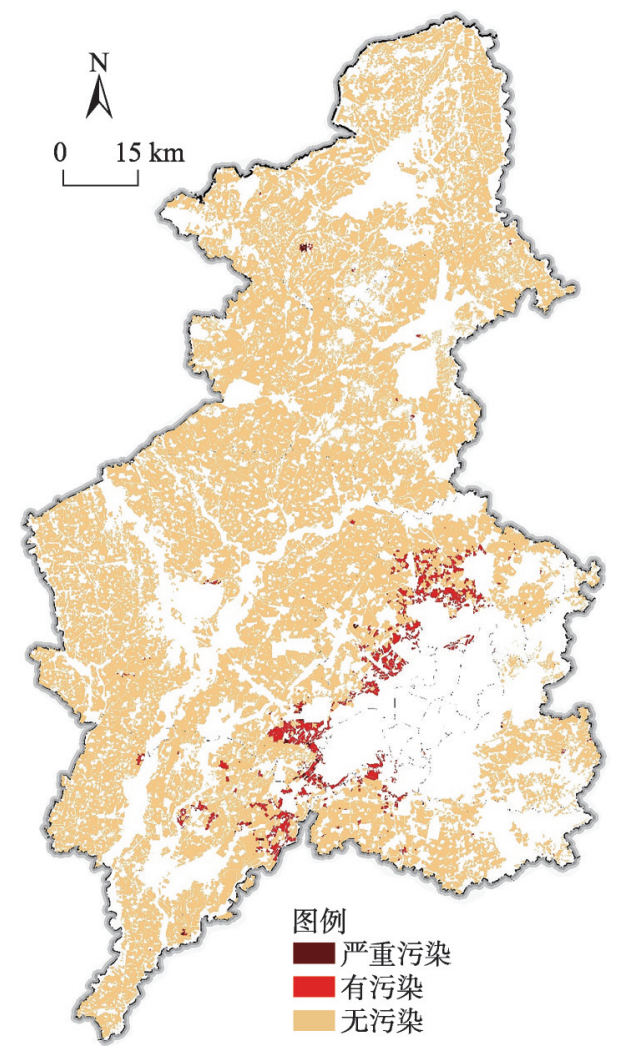

图 5 沈阳永久基本农田土壤环境质量评价

Fig. 5 Assessment of permanent farmland's soil environment quality

州市优势农业空间总面积 $653.08 \mathrm{~km}^{2}$, 占温州市国土面积的 $5.4 \%$, 包含 342 个村庄单元 (图 10)。

\section{3 结论与讨论}

优势农业空间概念的提出以永久基本农田红线管控思路为基础，弥补了市县 “双评 价” 中农业空间划定只重视基本农田和粮食生产，忽视大农业生产和农村聚落保护的不 足。优势农业空间的划定有利于明确未来农业生产、农村生活的核心空间布局，保障粮 食和特色农副产品生产安全、促进农村高效现代化建设和保护传统乡村历史文化遗存, 同时与城镇开发边界和生态保护红线相衔接，控制城镇建设规模和范围；进一步保护农 村生态环境和传承乡村地域特色。

本文使用精准、简易的评价指标与定量化、模型化的评价方法，构建了市县国土空 间规划 “双评价” 中优势农业空间划定的技术框架。该方法具有以下优势：（1）在评价 方法方面，对传统的 “双评价” 方法进行了优化，引人 TOPSIS 法和判别矩阵等定量模型 开展多要素综合评价, 使评价结果更具科学性;（2）在评价内容方面, 对评价要素进行 了补充和细化, 在省级农业生产适宜性评价结果之上增加市县级评价对农业生产经营、 地域特色优势农产品、特色重点村落和重大农业基础设施要素的考虑, 强化对农业生产 区、现代化农村和传统乡村地域文化的全要素保护;（3）在评价指标方面，增加农产品 


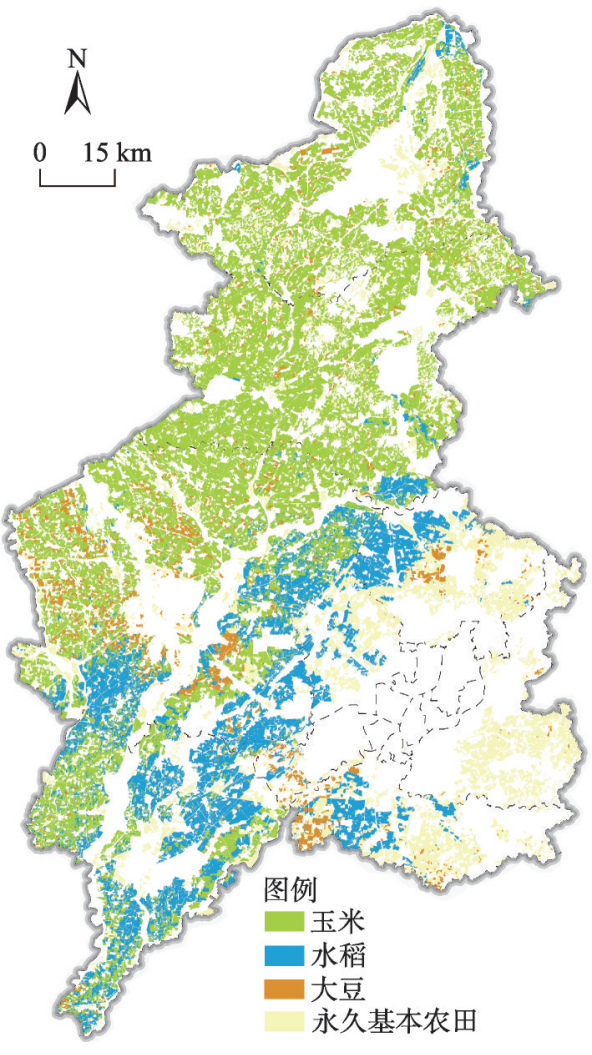

图6 沈阳粮食和重要农产品集中生产区

Fig. 6 Production areas of grain and important agricultural products

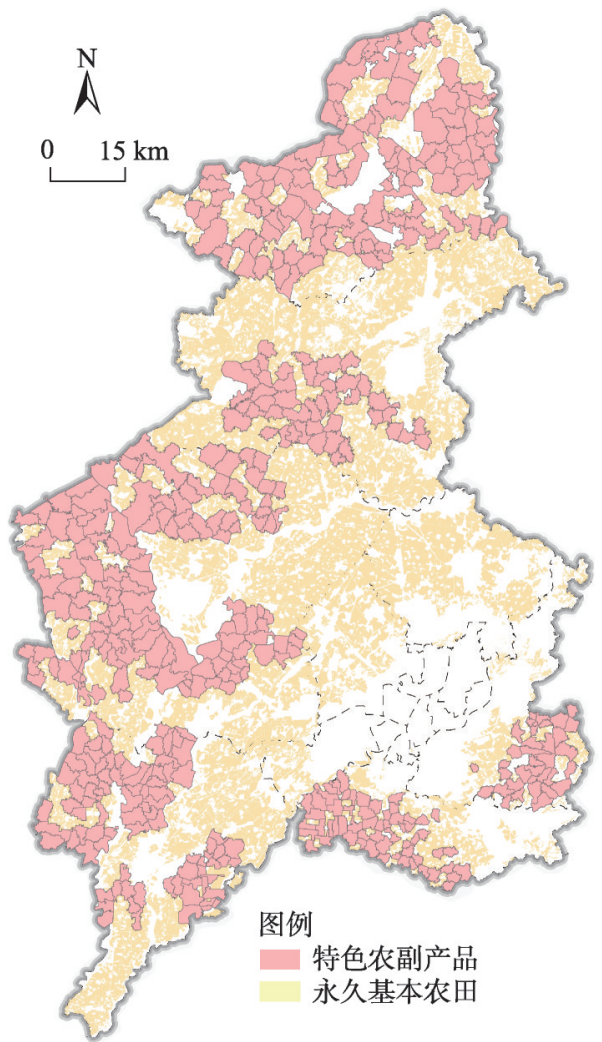

图 7 沈阳地域特色优势农产品集中生产区

Fig. 7 Production areas of local agricultural specialties

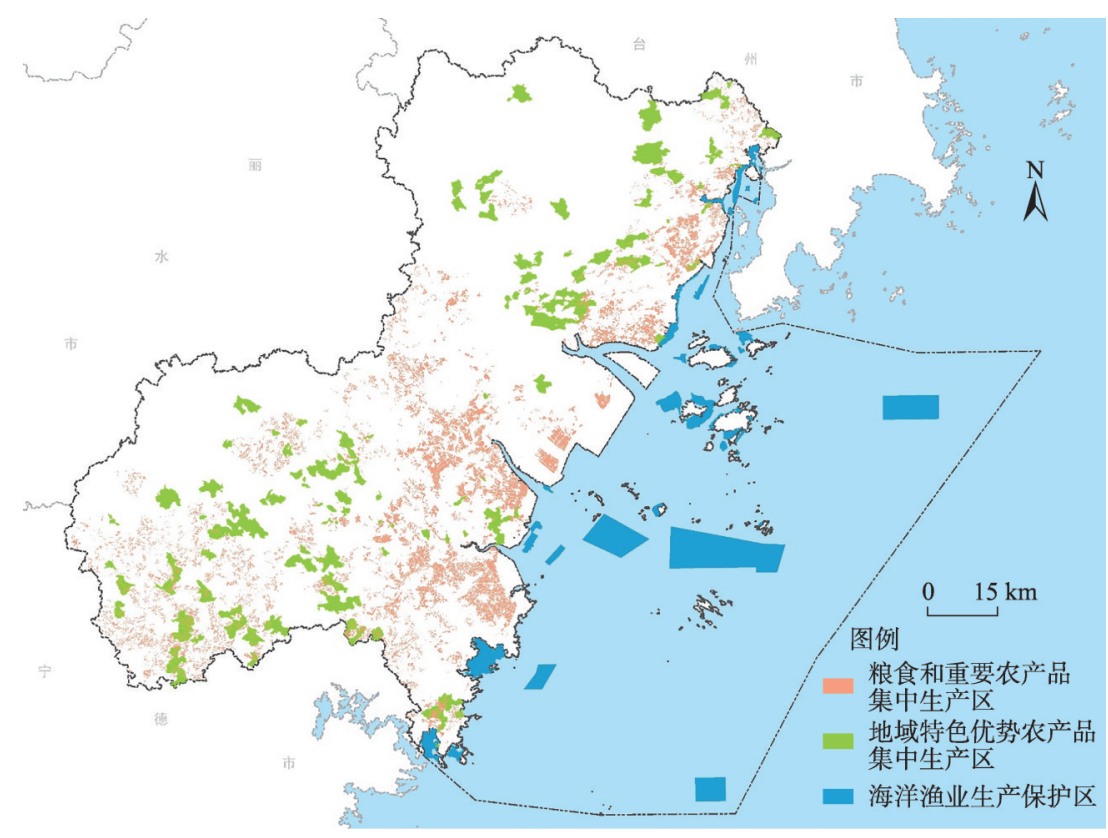

图 8 温州农业和海洋渔业生产保护区

Fig. 8 Protection areas of agricultural and marine fishery production 
产量和农业生产经营规模等指标, 提升市县层面 评价结果的精度，在服务于国土空间规划编制方 面发挥更好的支撑作用。

面向农业空间保护与布局优化，优势农业空 间的评价成果不仅依托永久基本农田保护红线保 障耕地和粮食生产安全, 而且强化了农林牧副渔 大农业空间、全农业领域生产者和特色重点农村 地区的整体保护，为国土空间规划体系中的县域 地区重点农业空间保护区和农业产业项目集中建 设区的安排与部署提供更强的指导意义; 面向乡 村振兴下的乡村规划编制与实施，优势农业空间 囊括粮食和重要农产品生产区、地域特色优势农 产品生产区、特色重点村落和重大农业基础设施 等农村地区有保护、利用与发展价值的要素, 具 有促进农业农村高效产业化和现代化建设和保护 传统乡村历史文化遗存的积极作用，为乡村振兴 投人以及市县级国土空间规划中乡村地区的详细 规划编制和实施框定了重点; 面向国土空间规划 “三区三线”的划定和管控，划定的优势农业空间 与城镇开发边界和生态保护红线相衔接, 为城镇 开发建设提供了限定屏障, 有利于约束以侵占农

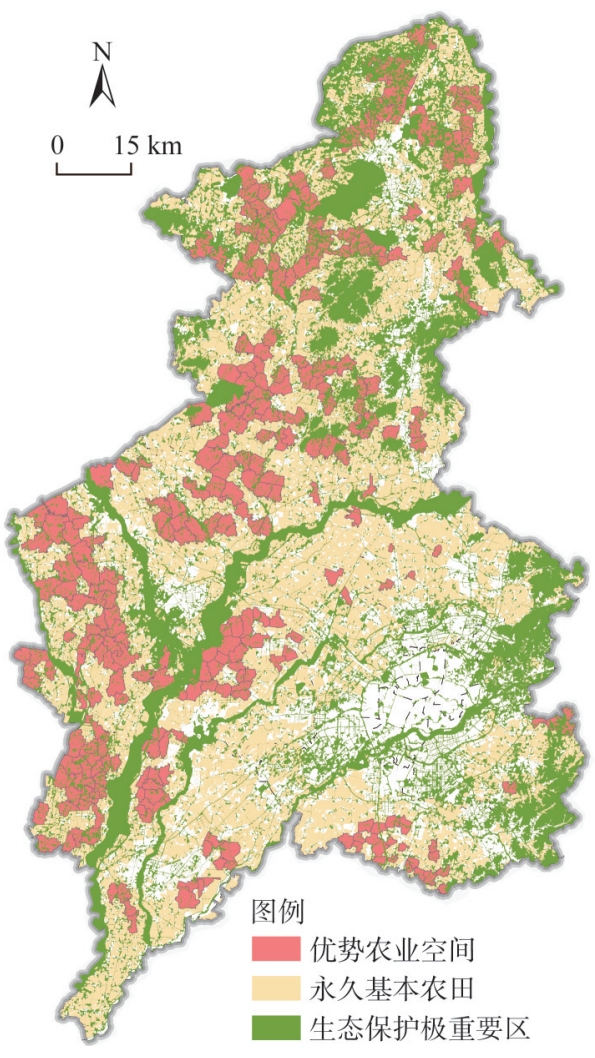

图9 沈阳优势农业空间划定

Fig. 9 Superior agricultural space in Shenyang

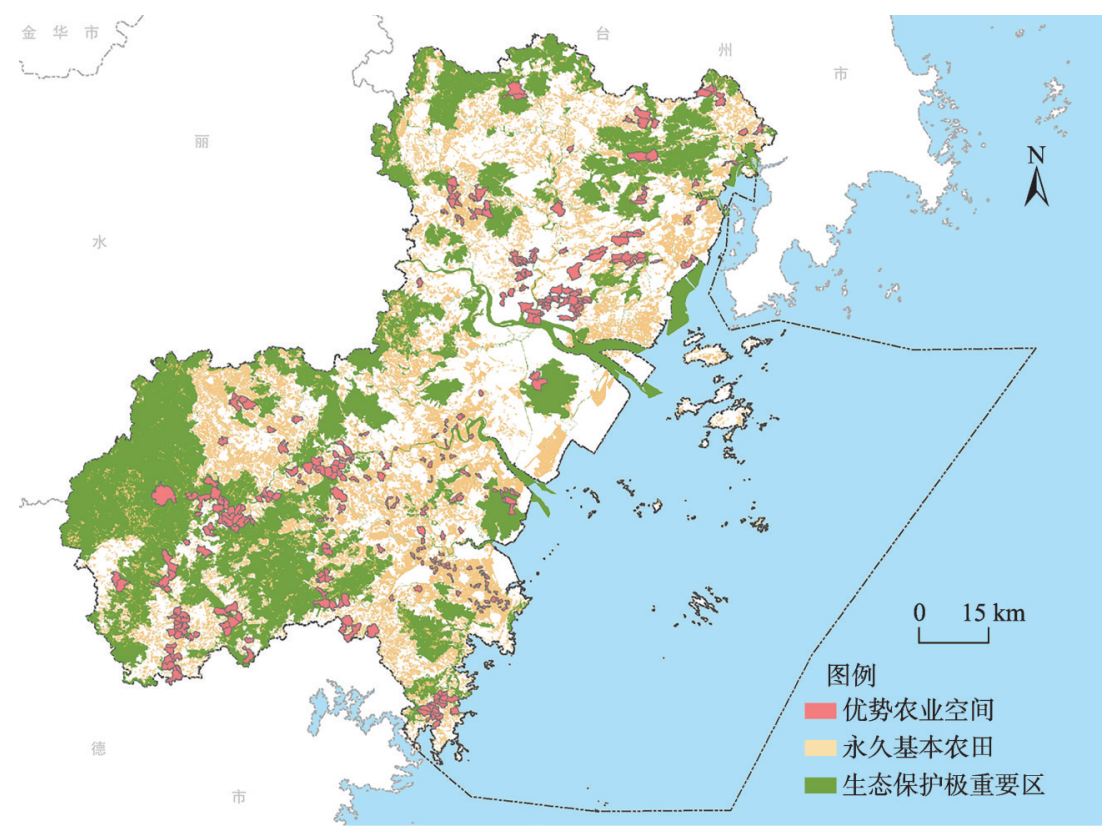

图 10 温州优势农业空间划定

Fig. 10 Superior agricultural space in Wenzhou 
业空间和生态空间为代价的城镇过度扩张，促进城镇空间的集聚和优化发展。

综上所述，本文所构建的优势农业空间划定理论框架和技术方法满足科学性、实用 性和可落地性的要求，不仅满足了市县级 “双评价” 层面对地方农业生产自然本底条件 的深度评价需求，甄别区域资源环境突出问题的同时能够进一步服务于国土空间规划编 制，明确空间发展的潜力规模及分布范围，为实现国土空间规划关键性理论与技术创新 提供了新的视角。当然也要看到，本文构建的优势农业空间划定理论与方法还存在有待 后续研究探索之处。一方面，优势农业空间评价与传统农业生产适宜性评价的结合关系 还有待进一步理顺，目前由于两者在评价指标和评价方法上均存在较大差异，评价结果 的衔接还比较生硬，更多表现为两者分别为国土空间规划编制提供依据。另一方面，本 文实证研究部分结合沈阳、温州两地实际情况差异化遴选了评价指标和分级國值，但从 推广应用角度看, 还需要对评价指标和阈值划分做进一步系统研究, 这有赖于更广泛的 实践案例支撑。

\section{参考文献(References):}

[1] 顾朝林. 论新时代国土空间规划技术创新. 北京规划建设, 2019, 33(4): 64-70. [GU C L. On technical innovation of territorial spatial planning in the New Era. Beijing Planning Review, 2019, 33(4): 64-70.]

[2] 韩青, 孙中原, 孙成苗, 等. 基于自然资源本底的国土空间规划现状一张图构建及应用: 以青岛市为例. 自然资源学 报, 2019, 34(10): 2150-2162. [HAN Q, SUN Z Y, SUN C M, et al. Establishment and application of one map of current situation of territorial spatial planning according to the foundations of natural resources: Taking Qingdao city as an example. Journal of Natural Resources, 2019, 34(10): 2150-2162.]

[3] 张年国, 王娜, 殷健. 国土空间规划“三条控制线”划定的沈阳实践与优化探索. 自然资源学报, 2019, 34(10): 21752185. [ZHANG N G, WANG N, YIN J. Shenyang's practice and optimizing exploration of "Three Control Lines" in territorial spatial planning. Journal of Natural Resources, 2019, 34(10): 2175-2185.]

[4] 顾朝林, 张晓明. 论县镇乡村域规划编制. 城市与区域规划研究, 2016, 8(2): 1-13. [GU C L, ZHANG X M. On planning compilation for rural China. Journal of Urban and Regional Planning, 2016, 8(2): 1-13.]

[5] 廖炳英. 基于划定“永久农村地区”的农村规划新框架. 城市与区域规划研究, 2016, 8(2): 14-23. [LIAO B Y. A new framework for regional planning in rural China based on the "Permanent Rural Areas". Journal of Urban and Regional Planning, 2016, 8(2): 14-23.]

[6] 中华人民共和国自然资源部. 关于全面开展国土空间规划工作的通知. http://www.gov.cn/zhengce/zhengceku/201910/14/content_5439428.htm, 2019-10-14. [Ministry of Natural Resources of the People's Republic of China. Circular on the full implementation of territorial spatial planning. http://www.gov.cn/zhengce/zhengceku/2019- 10/14/content 5439428. htm, 2019-10-14.]

[7] 吴次芳. 国土空间规划. 北京: 地质出版社, 2019: 72-84. [WU C F. Territorial Spatial Planning. Beijing: Geological Publishing House, 2019: 72-84.]

[8] 罗政, 方琴, 刘伦文, 等. 湖南省市县国土空间规划编制重点. 国土资源导刊, 2019, 16(3): 28-30. [LUO Z, FANG Q, LIU L W, et al. Key points of urban and county territorial spatial planning in Hunan province. Land and Resources Herald, 2019, 16(3): 28-30.]

[9] 强真. 新时期国土空间规划的职能构架与路径设计. 中国土地, 2019, 26(2): 22-25. [QIANG Z. Functional framework and path design of territorial space planning in the New Era. China Land, 2019, 26(2): 22-25.]

[10] 苏海龙. 市县国土空间规划编制工作探讨. 城乡规划, 2019, 8(2): 112-114. [SU H L. Discussion on the compilation of municipal and county territorial space planning. Urban and Rural Planning, 2019, 8(2): 112-114.]

[11] 顾朝林. 科学的 “双评价” 是新时代国土空间规划的关键和基础. 城市与区域规划研究, 2019, 11(2): 1-4. [GU C L. Scientific "Dual-evaluation" as the key and foundation for territorial spatial planning in the New Era. Journal of Urban and Regional Planning, 2019, 11(2): 1-4.]

[12] 贾铠阳, 乔伟峰, 王亚华, 等. 乡村振兴背景下村域尺度国土空间规划: 认知、职能与构建. 中国土地科学, 2019, 33 (8): 16-23. [JIA K Y, QIAO W F, WANG Y H, et al. Cognition, function and construction of village-scale territorial spatial planning against the background of rural vitalization. China Land Science, 2019, 33(8): 16-23.] 
[13] 温振民, 张永科. 用高稳系数法估算玉米杂交种高产稳产性的探讨. 作物学报, 1994, 20(4): 508-512. [WEN Z M, ZHANG Y K. Estimation of high and stable yield ability of hybrid maize cultivars by using high stability coefficient method. Acta Agronomica Sinica, 1994, 20(4): 508-512.]

[14] 高洪军, 彭畅, 张秀芝, 等. 长期不同施肥对东北黑土区玉米产量稳定性的影响. 中国农业科学, 2015, 48(23): 47904799. [GAO H J, PENG C, ZHANG X Z, et al. Effect of long-term different fertilization on maize yield stability in the northeast black soil region. Scientia Agricultura Sinica, 2015, 48(23): 4790-4799.]

[15] 古世禄, 独俊娥, 古兆明, 等. 中国北部高原地区谷子(粟)品种高产稳产性的评价. 中国农业科学, 2001, 34(4): 454457. [GU S L, DU J E, GU Z M, et al. Evaluation on high and stable yield ability of foxtail millet in the north high plateau area in China. Scientia Agricultura Sinica, 2001, 34(4): 454-457.]

[16] 刘兆晔, 韩启秀, 于经川, 等. 山东省小麦新品种(系)高产稳产性分析. 中国农学通报, 2005, 21(2): 136-137. [LIU Z Y, HAN Q X, YU J C, et al. The high yield stability analysis of new wheat varieties in Shandong province. Chinese Agricultural Science Bulletin, 2005, 21(2): 136-137.]

[17] 许庆, 尹荣梁, 章辉. 规模经济、规模报酬与农业适度规模经营: 基于我国粮食生产的实证研究. 经济研究, 2011, 46 (3): 59-71. [XU Q, YIN R L, ZHANG H. Economies of scale, returns to scale and the problem of optimum-scale farm management: An empirical study based on grain production in China. Economic Research Journal, 2011, 46(3): 59-71.]

[18] 张兰, 冯淑怡, 陆华良, 等. 农地规模经营影响因素的实证研究: 基于江苏省村庄调查数据. 中国土地科学, 2015, 29 (11): 32-39. [ZHANG L, FENG S Y, LU H L, et al. Empirical analysis on influencing factors of farmland scale management: Based on the survey data of sample villages in Jiangsu province. China Land Science, 2015, 29(11): 32-39.]

[19] 张红宇. 新型农业经营主体发展趋势研究. 经济与管理评论, 2015, 31(1): 104-109. [ZHANG H Y. Research on the development trend of new agricultural management subject. Review of Economy and Management, 2015, 31(1): 104109.]

[20] 黄祖辉, 俞宁. 新型农业经营主体: 现状、约束与发展思路: 以浙江省为例的分析. 中国农村经济, 2010, 26(10): 1626. [HUANG Z H, YU N. Status, restriction and development of new agricultural management subject: A case study in Zhejiang province. Chinese Rural Economy, 2010, 26(10): 16-26.]

[21] 张照新, 赵海. 新型农业经营主体的困境摆脱及其体制机制创新. 改革, 2013, 26(2): 78-87. [ZHANG Z X, ZHAO H. The way-out of the new agricultural management entities and its system and mechanism innovation. Reform, 2013,26 (2): 78-87.]

[22] 张红宇. 中国现代农业经营体系的制度特征与发展取向. 中国农村经济, 2018, 34(1): 23-33. [ZHANG H Y. Institutional features and development direction of China's modern agricultural management. Chinese Rural Economy, 2018, 34(1): 23-33.]

[23] 何秀荣. 关于我国农业经营规模的思考.农业经济问题, 2016, 37(9): 4-15. [HE X R. Thoughts on the moderate scale management of agriculture in China. Issues in Agricultural Economy, 2016, 37(9): 4-15.]

[24] 郭庆海. 土地适度规模经营尺度: 效率抑或收人. 农业经济问题, 2014, 35(7): 4-10. [GUO Q H. The evaluation criterion of moderate land-scale operation: Efficiency or income. Issues in Agricultural Economy, 2014, 35(7): 4-10.]

[25] 卫新, 毛小报, 王美清. 浙江省农户土地规模经营实证分析. 中国农村经济, 2003, 19(10): 31-36. [WEI X, MAO X B, WANG M Q. A positive study on optimal scale of farmland for operation by rural households in Zhejiang province. Chinese Rural Economy, 2003, 19(10): 31-36.]

[26] 钱贵霞, 李宁辉. 粮食主产区农户最优生产经营规模分析. 统计研究, 2004, 21(10): 40-43. [QIAN G X, LI N H. The analysis of optimized operating scale of farms in main cereal producing areas. Statistical Research, 2004, 21(10): 40-43.]

[27] 杨钢桥, 胡柳, 汪文雄. 农户耕地经营适度规模及其绩效研究: 基于湖北 6 县市农户调查的实证分析. 资源科学, 2011, 33(3): 505-512. [YANG G Q, HU L, WANG W X. Moderate scale of farmers' cultivated land management and its performance: An empirical analysis based on questionnaire survey of rural households in 6 counties in Hubei province. Resources Science, 2011, 33(3): 505-512.]

[28] 倪国华, 蔡昉. 农户究竟需要多大的农地经营规模: 农地经营规模决策图谱研究. 经济研究, 2015, 50(3): 159-171. [NI G H, CAI F. What is the proper land management scale really needed by farmers?. Economic Research Journal, 2015, 50(3): 159-171.]

[29] 胡初枝, 黄贤金. 农户土地经营规模对农业生产绩效的影响分析: 基于江苏省铜山县的分析. 农业技术经济, 2007, 26(6): 81-84. [HU C Z, HUANG X J. Influence of land management scale of the farm households on agricultural productivity: A case study in Tongshan county, Jiangsu province. Journal of Agrotechnical Economics, 2007, 26(6): 81-84.]

[30] 董雪娇, 汤惠君. 国内外农地规模经营述评. 中国农业资源与区划, 2015, 36(3): 62-71. [DONG X J, TANG H J. A review on the scale operation of farmland worldwide. Chinese Journal of Agricultural Resources and Regional Planning, 
2015, 36(3): 62-71.]

[31] 张成玉. 土地经营适度规模的确定研究: 以河南省为例. 农业经济问题, 2015, 36(11): 57-63. [ZHANG C Y. How to calculate the moderate scales of farmland in China: Case study in Henan province. Issues in Agricultural Economy, 2015, 36(11): 57-63.]

[32] 林万龙. 农地经营规模: 国际经验与中国的现实选择. 农业经济问题, 2017, 38(7): 33-42. [LIN W L. Farm size: International experience and the realistic choice of China. Issues in Agricultural Economy, 2017, 38(7): 33-42.]

[33] PIRNAT J. Conservation and management of forest patches and corridors in suburban landscapes. Landscape and Urban Planning, 2000, 52(2): 135-143.

[34] DE BARROS FERRAZ S F, VETTORAZZI C A, THEOBALD D M, et al. Landscape dynamics of Amazonian deforestation between 1984 and 2002 in Central Rondônia, Brazil: Assessment and future scenarios. Forest Ecology and Management, 2005, 204(1): 69-85.

[35] NIKOLAKAKI P. A GIS site-selection process for habitat creation: Estimating connectivity of habitat patches. Landscape and Urban Planning, 2004, 68(1): 77-94.

[36] 周尚意, 朱阿兴, 邱维理, 等. 基于 GIS 的农用地连片性分析及其在基本农田保护规划中的应用. 农业工程学报, 2008, 24(7): 72-77. [ZHOU S Y, ZHU A X, QIU W L, et al. GIS based connectivity analysis and its application in prime farmland protection planning. Transactions of the CSAE, 2008, 24(7): 72-77.]

[37] 段刚. 基于农用地定级的基本农田保护空间规划方法研究. 西安: 长安大学, 2009. [DUAN G. Study on the method of basic farmland protection spatial planning in basis of agricultural land classification. Xi'an: Chang'an University, 2009.]

[38] 鲁学军, 武鹏达, 郭旭东. 二值形态闭运算在优质耕地集中连片划定中的应用. 中国图象图形学报, 2016, 21(2): 199-206. [LU X J, WU P D, GUO X D. Application of binary morphological closing operation for aggregation connectivity planning in high-quality arable land. Journal of Image and Graphics, 2016, 21(2): 199-206.]

[39] 张保华, 王雷, 白振华, 等. 基于景观格局指数的基本农田保护区集中连片性研究: 以济南市历城区为例. 山东国土 资源, 2014, 30(2): 80-82. [ZHANG B H, WANG L, BAI Z H, et al. Study on integrity and continuity of basic farmland protection based on landscape pattern index: Setting Licheng district in Jinan city as an example. Shandong Land and Resources, 2014, 30(2): 80-82.]

[40] RICOTTA C A, STANISCI A, AVENA G C, et al. Quantifying the network connectivity of landscape mosaics: A graphtheoretical approach. Community Ecology, 2000, 1(1): 89-94.

[41] MARULLI J, MALLARACH J M. A GIS methodology for assessing ecological connectivity: Application to the Barcelona Metropolitan Area. Landscape and Urban Planning, 2005, 71(2): 243-262.

[42] 杨建宇, 赵龙, 徐凡, 等. 基于耕地连片度的高标准基本农田建设划区. 农业机械学报, 2017, 48(4): 142-148. [YANG J Y, ZHAO L, XU F, et al. Zoning of high standard prime farmland construction based on arable lands connectivity. Transactions of the CSAM, 2017, 48(4): 142-148.]

[43] 任宇飞, 方创琳. 京津冀城市群县域尺度生态效率评价及空间格局分析. 地理科学进展, 2017, 36(1): 87-98. [REN Y F, FANG C L. Spatial pattern and evaluation of eco-efficiency in counties of the Beijing-Tianjin-Hebei Urban Agglomeration. Progress in Geography, 2017, 36(1): 87-98.]

[44] 马雪芗, 邵景安, 徐新良. 基于熵权-TOPSIS 的山区乡镇通达性研究: 以重庆市石柱县为例. 地理科学进展, 2016, 35 (9): 1144-1154. [MA X Y, SHAO J A, XU X L. Rural transportation accessibility in mountainous areas based on the entropy-weight TOPSIS method: A case study of Shizhu county, Chongqing Municipality. Progress in Geography, 2016, 35 (9): 1144-1154.]

[45] 文高辉, 杨钢桥, 汪文雄, 等. 基于农户视角的耕地细碎化程度评价: 以湖北省“江夏区一咸安区一通山县”为例. 地 理科学进展, 2016, 35(9): 1129-1143. [WEN G H, YANG G Q, WANG W X, et al. Evaluation of cultivated land fragmentation degree based on farmers' perspective: A case of Jiangxia district, Xian'an district and Tongshan county in Hubei province. Progress in Geography, 2016, 35(9): 1129-1143.]

[46] LAI Y J, LIU T Y, HWANG C L. TOPSIS for MODM. European Journal of Operational Research, 1994, 76(3): $486-500$.

[47] 郝庆, 邓玲, 封志明. 国土空间规划中的承载力反思: 概念、理论与实践. 自然资源学报, 2019, 34(10): 2073-2086. [HAO Q, DENG L, FENG Z M. Carrying capacity reconsidered in spatial planning: Concepts, methods and applications. Journal of Natural Resources, 2019, 34(10): 2073-2086.] 


\title{
The superior agricultural space demarcation based on the evaluation of resources and environmental carrying capacity and territorial spatial development suitability at municipality and county levels:
}

\author{
Theories, methods and study of two cases
}

\author{
SU He-fang ${ }^{1}$, CAO Gen-rong ${ }^{1}$, GU Chao-lin', JIN Jia-liang ${ }^{2}$, \\ ZHANG Xiao-ming ${ }^{3}$, YI Hao-lei ${ }^{1}$, ZHENG Yi ${ }^{1}$, FU Qiang ${ }^{4}$ \\ (1. School of Architecture, Tsinghua University, Beijing 100084, China; 2. Chinese Institute of Urban Scientific \\ Planning and Design, Beijing 100835, China; 3. China Center for Urban Development, National Development \\ and Reform Commission, Beijing 100824, China; 4. College of Civil Engineering and Architecture, Shandong \\ University of Science and Technology, Qingdao 266590, Shandong, China)
}

\begin{abstract}
China's urbanization has started to rapidly encroach on the most valuable arable land resources and rural settlements, and it has therefore become extremely urgent to protect basic farmland, rural areas and agricultural space. However, for a brand- new round of territorial spatial planning at city and county level, with "the evaluation of resources and environmental carrying capacity and territorial spatial development suitability" which plays a fundamental role in spatial planning, emphasis is only placed on basic farmland and food production in agricultural areas. Therefore, the purpose of this paper is to optimize the theoretical and technical scheme of evaluation of "superior agricultural space", in order to serve as a foundation for protecting agricultural space, all agricultural producers and large rural areas. The technical methods employed in this paper are as follows. (1) A total-region and total-factor evaluation of suitability for farming, animal husbandry and fishery production is conducted outside the area of vital importance for ecological protection and the area of the ecological red line, dividing the space into "suitable regions for agricultural production" and "unsuitable regions for agricultural production". (2) Based on the evaluation principles of high stability, large-scale management and land connectivity, a TOPSIS model is constructed in order to further evaluate and demarcate suitable regions for producing grain and other important agricultural products and for producing special local agricultural products. (3) Based on the aforementioned points, superior agricultural space is identified by a multi-factor comprehensive evaluation procedure, taking characteristic and important rural areas and large agricultural infrastructure into consideration. The two cases in Shenyang and Wenzhou are adopted as examples for the study in order to demonstrate the validity, feasibility and practicability of our method. It is also proven that the evaluation and delineation of the superior agricultural space can assist the development and protection of territorial space at city and county level.
\end{abstract}

Keywords: superior agricultural space; territorial spatial planning; urbanization; agricultural space protection; multi-factor comprehensive evaluation 